\title{
Modulation of B lymphocyte function by an aqueous fraction of the ethanol extract of Cissampelos sympodialis Eichl (Menispermaceae)
}

M.S. Alexandre-Moreira ${ }^{1}$, M.R. Piuvezam ${ }^{2}$ and L.M.T. Peçanha ${ }^{1}$

\section{Correspondence}

L.M.T. Peçanha

Departamento de Imunologia

Instituto de Microbiologia, UFRJ

CCS, Bloco I, Ilha do Fundão

21944-570 Rio de Janeiro, RJ

Brasil

Fax: +55-21-2560-8344

E-mail: Ipecanha@micro.ufrj.br

Research supported by CNPq, FINEP, PRONEX-MCT, and FAPERJ.

M.S. Alexandre-Moreira was the recipient of a CAPES/MEC fellowship. $\ldots \ldots \ldots \ldots \ldots \ldots \ldots$

Received February 21, 2003 Accepted July 18, 2003
1'Departamento de Imunologia, Instituto de Microbiologia Prof. Paulo de Góes, Universidade Federal do Rio de Janeiro, Rio de Janeiro, RJ, Brasil

${ }^{2}$ Laboratório de Tecnologia Farmacêutica, Departamento de Fisiologia e Patologia, Universidade Federal da Paraíba, João Pessoa, PB, Brasil

\begin{abstract}
Cissampelos sympodialis Eichl species are used in folk medicine for the treatment of asthma, arthritis and rheumatism. In the present study, we investigated the immunomodulatory effect of an aqueous fraction of a $70 \%(\mathrm{v} / \mathrm{v})$ ethanol extract of $C$. sympodialis leaves on B lymphocyte function. The hydroalcoholic extract inhibited the in vitro proliferative response of resting B cells induced by LPS $\left(\mathrm{IC}_{50}=17.2 \mu \mathrm{g} / \mathrm{ml}\right)$, anti-delta-dextran $\left(\mathrm{IC}_{50}=13.9 \mu \mathrm{g} / \mathrm{ml}\right)$ and anti-IgM $\left(\mathrm{IC}_{50}=24.3 \mu \mathrm{g} /\right.$ $\mathrm{ml}$ ) but did not affect the anti-MHC class II antibody-stimulated proliferative response of B cell blasts obtained by stimulation with IL4 and anti-IgM. Incubation with the hydroalcoholic extract used at 50 $\mu \mathrm{g} / \mathrm{ml}$ induced a $700 \%$ increase in intracellular cAMP levels. IgM secretion by resting $\mathrm{B}$ cells (obtained from normal mice) and polyclonally activated B cells (obtained from Trypanosoma cruziinfected animals) was inhibited by the hydroalcoholic extract. The latter were more sensitive to the hydroalcoholic extract since $6.5 \mu \mathrm{g} /$ $\mathrm{ml}$ induced a $20 \%$ inhibition in the response of cells from normal mice while it inhibited the response of B cells from infected animals by $75 \%$. The present data indicate that the alcoholic extract of $C$. sympodialis inhibited B cell function through an increase in intracellular cAMP levels. The finding that the hydroalcoholic extract inhibited immunoglobulin secretion suggests a therapeutic use for the extract from $C$. sympodialis in conditions associated with unregulated $B$ cell function and enhanced immunoglobulin secretion. Finally, the inhibitory effect of the hydroalcoholic extract on B cells may indicate an anti-inflammatory effect of this extract.
\end{abstract}

Key words - B lymphocytes

- Cissampelos sympodialis

- Natural products

- Trypanosoma cruzi

- Immunoglobulin

\section{Introduction}

Cissampelos sympodialis Eichl (Menispermaceae) is a species found in the Northeast and Southeast of Brazil. A hot water infusion of the fresh root bark of $C$. sympodialis is used in folk medicine for the treatment of asthma, arthritis and rheumatism, among other conditions (1). Phytochemical studies of root extracts from $C$. sympodialis species have indicated the presence of aporfinic, bisbenzyltetrahydroiso- 
quinolinic and tetrahydroprotoberberinic alkaloids (2,3). Phytochemical studies culminated with the isolation of three tertiary alkaloids (wariftein, methylwariftein and millonin), one quaternary alkaloid (laurifolin), and an alkaloid showing a morphinanic skeleton (milonine) $(1,4)$. Wariftein was shown to be a component with spasmolytic action (4).

Pharmacological studies showed that the extract of $C$. sympodialis relaxed tracheal smooth muscle and inhibited bronchospasm induced by histamine in normal and ovalbumin-sensitized guinea pigs (5). It was also shown that the aqueous fraction of a $70 \%$ ethanol extract of the leaves of C. sympodialis significantly increased the number of mononuclear cells in the bronchoalveolar lavage fluid, suggesting a possible chemotactic activity (1). The hydroalcoholic extract also inhibited the TPA- and capsaicin-induced mouse ear edema and neutrophil migration to the rat peritoneal cavity, indicating an anti-inflammatory activity of this hydroalcoholic extract (6). The extract of C. sympodialis inhibited the activity of the phosphodiesterases IV and V isolated from guinea pig lungs. The leaf extract also increased cAMP levels in cultured tracheal smooth muscle cells (7). Studies using human peripheral blood neutrophils demonstrated that the ethanol extract of the leaves of $C$. sympodialis inhibited degranulation of these cells stimulated with formyl-Met-Phe-Pro, increased the levels of cAMP, and increased the activity of cAMP-dependent protein kinase A (8). One of the alkaloids derived from the extract, wariftein, also inhibited calcium influx through voltage-operated calcium channels in guinea pig ileum and rat uterus and was suggested to be a nonspecific inhibitor of smooth muscle contraction (9). Finally, immunological studies showed that the hydroalcoholic extract inhibited the in vitro proliferative response of $\mathrm{T}$ cells induced by concanavalin A and decreased the secretion of both IL-2 and IFN- $\gamma(10)$. Despite this inhibition of the secretion of these cytokines, there was an increase in the secretion of the type 2 cytokines IL-4 and IL-10 (10). The hydroalcoholic extract was also shown to inhibit the microbicidal activity of peritoneal macrophages and to increase IL-10 secretion by these cells (11).

Several studies have characterized the events associated with B cell activation in vitro. B cell proliferation can be induced by the binding of stimuli to membrane immunoglobulin (for instance, in vitro stimulation with soluble anti-IgM antibodies or dextranconjugated anti-immunoglobulin antibodies) or by polyclonal activators like lipopolysaccharide (LPS) (12). Binding to surface class II MHC molecules also induces intracellular signals in B cells (13). Studies using antiMHC class II antibodies showed that the binding of these antibodies induced an increase in B cell cytoplasmic cAMP level (14). B cells are also induced to secrete immunoglobulin and the ability to present this response and the isotype profile produced depend on the nature of the $\mathrm{B}$ cell activator and on the presence of cytokines (15).

Ethnopharmacological studies have shown that the frequent intake of a hot water infusion of $C$. sympodialis by asthmatic individuals improves their clinical status. Asthma has an immunological component associated with the maintenance of the pathological state (16). Therefore, to better characterize the anti-asthmatic effect of the C. sympodialis extract, it would be important to obtain more detailed knowledge about the modulation of immunological function by the extract.

In the present study we investigated the modulation of B lymphocyte function by the aqueous fraction of a $70 \%(\mathrm{v} / \mathrm{v})$ ethanol extract of $C$. sympodialis. We analyzed its effect on both B cell proliferation and immunoglobulin secretion and showed that the effect of the hydroalcoholic extract on B cells is mediated by an increase in intracellular cAMP levels. 


\section{Material and Methods}

Preparation of the aqueous fraction from the ethanol extract of $C$. sympodialis Eichl

Leaves of C. sympodialis were collected at the Botanical Garden of the Laboratory of Pharmaceutical Technology (Federal University of Paraíba) and voucher specimens were deposited under code Agra 1456 in the herbarium of the Department of Botany. The leaves were dried at $40^{\circ} \mathrm{C}$ in an oven and then pulverized. The dry material was extracted with $70 \%$ ethanol (v/v) at $25-30^{\circ} \mathrm{C}$ for 3 days and the material obtained was dried at $60^{\circ} \mathrm{C}$ in a rotary evaporator. The yield was approximately $21 \%$ of the weight of the dried leaves. The dried fraction was suspended in water, filtered and known volumes were dried to determine the concentration of water-soluble material. Approximately $70 \%$ of the solids in the $70 \%$ ethanol extract were soluble in water. This water-soluble material is cited as hydroalcoholic extract throughout the text. The water-soluble material was dissolved in RPMI 1640 medium (Sigma, St. Louis, MO, USA). Nuclear magnetic resonance and fast atom bombardment mass spectrometry analysis, performed as previously described (17), revealed no contamination with bacterial LPS on the basis of the absence of the KDO LPS-cleavage product.

\section{Animals and Trypanosoma cruzi infection}

Male and female BALB/c mice were used at ages from 6 to 8 weeks. The animals were supplied by the Central Animal Facility from the Institute of Microbiology (Federal University of Rio de Janeiro) and were bred and housed in this animal facility according to institutional policies for animal care and use.

Epimastigote forms of the DM28c clone of $T$. cruzi were grown in brain-heart infusion medium supplemented with hemin ( 25 $\mathrm{mg} / \mathrm{l})$ and fetal bovine serum $(10 \% \mathrm{v} / \mathrm{v})$.
After 7-8 days of culture, in vitro metacyclogenesis was induced chemically by inoculating the parasites in TAU-P medium and metacyclic trypomastigote forms were obtained after 72 to $120 \mathrm{~h}$ of culture (18). Mice were inoculated with parasites $\left(10^{5}\right)$ by intravenous injection and infection parameters were monitored as previously described (19).

\section{Reagents}

LPS extracted from Escherichia coli O111:B4 was obtained from Sigma. Dextran-coupled anti-IgD antibody (anti-deltadextran) was prepared as previously described (20) and was provided by Dr. James J. Mond (Biosynexus Inc., Gaithersburg, MD, USA). Murine recombinant IL-4 (specific activity $2 \times 10^{7} \mathrm{U} / \mathrm{mg}$ ) and IL-5 (specific activity $2 \times 10^{7} \mathrm{U} / \mathrm{mg}$ ) were obtained from BD Pharmingen (Costa Mesa, CA, USA). Anti-MHC class II antibody (clone AMS32.1) was also obtained from BD Pharmingen. Goat anti-mouse IgM antibody was obtained from Sigma.

\section{B cell purification}

A murine spleen cell suspension was treated with a mixture of antibodies (antiThy-1, anti-CD4 and anti-CD8) and Low Tox rabbit complement (Cedarlane Laboratories Ltd., Hornby, Ontario, Canada) as previously described (20). The purified B cells were applied to a Percoll gradient (Pharmacia, Uppsala, Sweden) prepared with Percoll solutions of 1.086, 1.081, 1.074 and $1.062 \mathrm{~g} /$ $\mathrm{ml}$ density (20). The gradients were spun at $1900 \mathrm{~g}$ for $15 \mathrm{~min}$ and high density (resting) $\mathrm{B}$ cells were recovered from the interface of the solutions with densities of 1.086 and $1.081 \mathrm{~g} / \mathrm{ml}$. Low density (in vivo preactivated) B cells were recovered from the interface of Percoll solutions with densities of 1.074 and $1.062 \mathrm{~g} / \mathrm{ml}$. These cells were used as source of B cells in the cultures and were incubated for different times in RPMI 1640 medium 
(Gibco-BRL, Grand Island, NY, USA) supplemented with $10 \%$ fetal bovine serum (Gibco-BRL), 2 mM L-glutamine (Sigma), $50 \mathrm{mM}$ 2-mercaptoethanol (Sigma) and 50 $\mathrm{mg} / \mathrm{ml}$ gentamicin. Flow cytometry analysis of the B cell preparation showed an 85 to $90 \% \mathrm{~B} 220^{+} \mathrm{B}$ cell preparation and less than $3 \%$ residual contamination with $\mathrm{T}$ cells.

\section{Proliferation assay}

Splenic B cells were cultivated on 96well flat bottom plates in the presence or absence of different activators, in a final volume of $0.2 \mathrm{ml}$ in supplemented RPMI 1640 medium. Cultures were run for $48 \mathrm{~h}$ and were then pulsed with $1 \mu \mathrm{Ci}$ of tritiated thymidine (Amersham Pharmacia Biotech, Buckinghamshire, UK) with specific activity of $5 \mathrm{Ci} / \mathrm{mmol}$ and incubated for an additional period of $18 \mathrm{~h}$. The cultures were harvested with a PHD model cell harvester (Cambridge Technology, Watertown, MA, USA) using glass fiber filters. The incorporation of tritiated thymidine was determined by liquid scintillation spectroscopy. The results are reported as the arithmetic mean of counts per minute (cpm) obtained for cultures run in triplicate.

\section{Culture system in the presence of anti-MHC class II antibody}

B cells were cultivated $\left(10^{6}\right)$ on 24-well plates for $24 \mathrm{~h}$ in the presence or absence of goat anti-mouse IgM antibody and IL-4, in a final volume of $1 \mathrm{ml}$ in supplemented RPMI 1640 medium. The cells were then recovered and recultivated on plates previously coated with anti-MHC class II antibody. Alternatively, some cultures were performed using uncoated plates in the presence of bacterial LPS. The incorporation of tritiated thymidine was assayed as described above. Plates (96 wells) covered with anti-MHC class II antibodies were obtained by incubation for $16 \mathrm{~h}$ at $4^{\circ} \mathrm{C}$ with a solution of mono- clonal anti-MHC class II antibody (10 $\mu \mathrm{g} / \mathrm{ml})$.

Measurement of immunoglobulin production by ELISA

Pooled supernatants from triplicate cultures, set up as described above, were obtained after 7 days of culture and IgM levels were measured by sandwich ELISA (21). Polystyrene assay plates (Corning Inc., Corning, NY, USA) were covered with goat antimouse IgM antibody (Sigma) diluted in PBS. The presence of mouse immunoglobulin in samples and standards was measured by the addition of alkaline phosphatase-labeled goat anti-mouse IgM antibody (Southern Biotech. Ass. Inc., Birmingham, AL, USA). The reaction was quantitated by the addition of $p$ nitrophenolphosphate (Sigma) and absorbance was measured at $405 \mathrm{~nm}$ with a model 550 plate reader (BioRad, Boston, MA, USA). The concentrations of IgM were obtained by standard curves constructed with purified mouse IgM (ICN Biomedicals Inc., Irvine, CA, USA).

\section{cAMP assay}

B cells were incubated on 24-well plates $\left(10^{6}\right.$ per well $)$ for $18 \mathrm{~h}$ in supplemented RPMI 1640 medium. Some cultures were treated with goat anti-mouse IgM antibody and IL-4. On the following day, the cells were harvested and stimulated with the indicated activators in the presence or absence of the hydroalcoholic extract $(50 \mu \mathrm{g} / \mathrm{ml})$ for $2 \mathrm{~h}$. This optimal incubation period and hydroalcoholic extract doses were determined in preliminary kinetic studies (data not shown). The samples were then obtained and cAMP levels were measured by an immunoenzymatic assay using the cAMP Biotrac EIA System from Amersham Pharmacia Biotech according to supplier instructions. Absorbance was measured in a model 550 plate reader (BioRad) using a $450-\mathrm{nm}$ filter. 


\section{Statistical analysis}

The results are reported as means $\pm \mathrm{SD}$. Statistical analysis was performed using the Student $t$-test for independent samples, with the level of significance set at $\mathrm{P}<0.05$.

\section{Results}

Effect of the hydroalcoholic extract on B cell response induced by different $B$ cell activators

We initially performed preliminary studies to rule out any toxic effect of the hydroalcoholic extract on B lymphocytes. The viability of resting and LPS-activated B cells was not affected when concentrations of the extract ranging from 6.5 to $100 \mu \mathrm{g} / \mathrm{ml}$ were

Figure 1. The hydroalcoholic extract of Cissampelos sympodialis Eichl inhibits the B cell proliferative response induced by different B cell activators.

$A$, High density spleen $B$ cells were cultivated $\left(2 \times 10^{5}\right.$ cells/well in $0.2 \mathrm{ml}$ ) for $48 \mathrm{~h}$ in the presence or absence of the indicated doses of lipopolysaccharide (LPS, in $\mu \mathrm{g} / \mathrm{mll}$. Some cultures were treated with varying doses of the hydroalcoholic extract. B cell proliferation was measured by the incorporation of $1 \mu \mathrm{Ci}$ tritiated thymidine after 18-h incubation. The data are reported as the percent inhibition of the response of cultures set up in the presence of the hydroalcoholic extract compared to control cultures without the addition of the extract. Control responses were as follows: LPS $(10 \mu \mathrm{g} / \mathrm{ml})$ $33,232 \mathrm{cpm}$, LPS $(1 \mu \mathrm{g} / \mathrm{ml}) 34,622 \mathrm{cpm}$, and LPS $(0.1$ $\mu \mathrm{g} / \mathrm{ml}) 32,410 \mathrm{cpm}$. Nonstimulated cultures showed incorporation of $1,212 \mathrm{cpm}$.

$B$, High density spleen $B$ cells were cultured under the same conditions as described in A. Different $B$ cell activators were added to the cultures: LPS $(10 \mu \mathrm{g} / \mathrm{ml})$, anti-delta-dextran $(10 \mathrm{ng} / \mathrm{ml})$ or goat anti-mouse $\mathrm{lgM}$ $(100 \mu \mathrm{g} / \mathrm{ml})$. The cultures were also treated with the indicated doses of the hydroalcoholic extract. The data are reported as the percent inhibition of the proliferative response observed in the presence of the hydroalcoholic extract compared to values for control untreated cultures. The values of control cultures were as follows: LPS, 36,230 cpm; anti-lgM, 4,579 cpm; anti-delta-dextran, $37,835 \mathrm{cpm}$. Tritiated thymidine incorporation of untreated cultures was $502 \mathrm{cpm}$. The reported data are the representative result of three independent experiments. ${ }^{*} P<0.05$ for cultures treated with the extract compared to untreated cultures (Student $t$-test). used (data not shown). We next assayed whether the extract would have any effect on the resting $B$ cell response induced by different $\mathrm{B}$ cell activators. We observed that in vitro it inhibited B cell proliferation induced by different concentrations of LPS (Figure 1A). The hydroalcoholic extract also inhibited B cell proliferation stimulated with dextran-conjugated anti-IgD antibody (anti-deltadextran) and anti-IgM antibodies (Figure 1B). The $\mathrm{IC}_{50}$ for the extract calculated using data

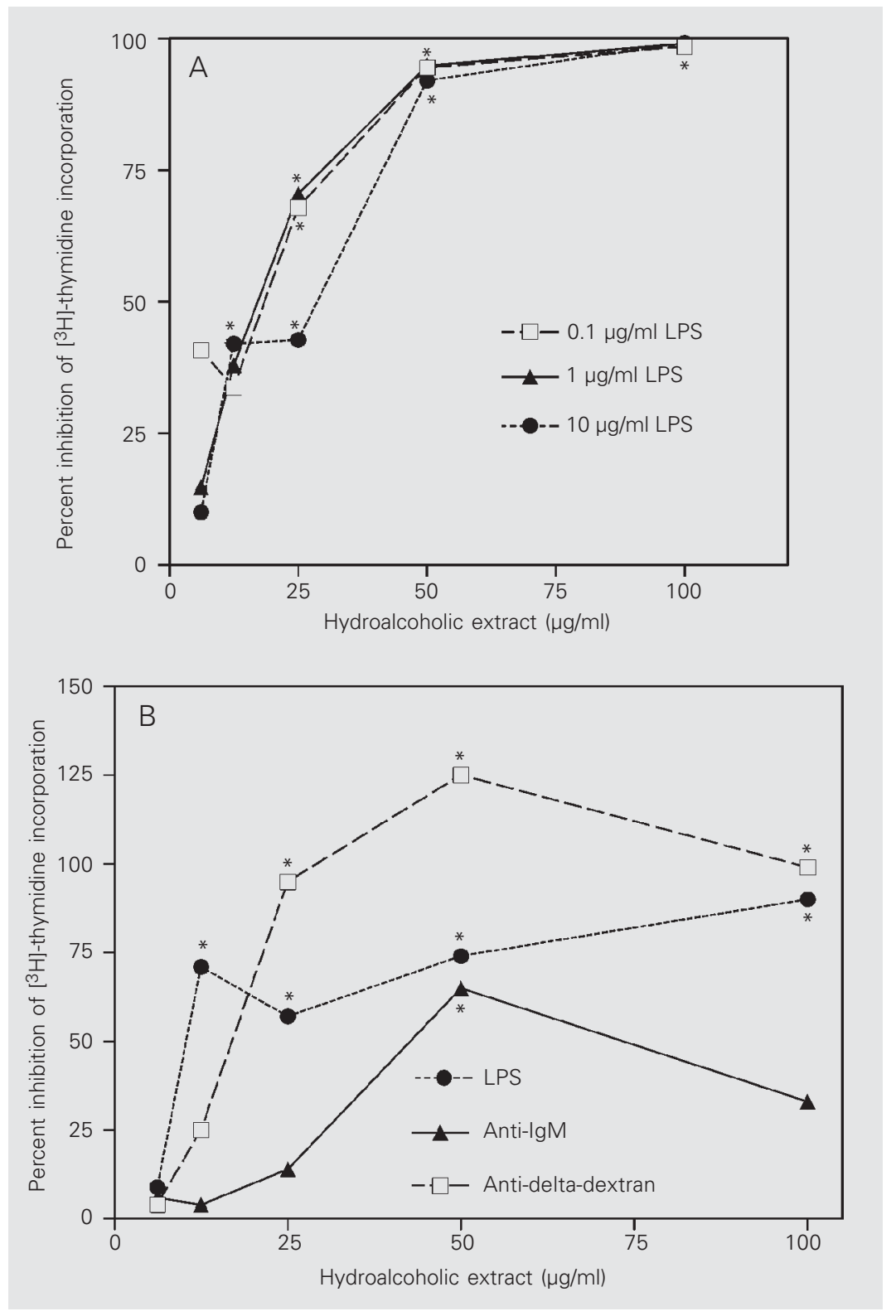


from at least three proliferation assays were as follows: LPS, $17.2 \pm 2 \mu \mathrm{g} / \mathrm{ml}$; anti-IgM, $24.3 \pm 2.2 \mu \mathrm{g} / \mathrm{ml}$, and anti-delta-dextran, $13.9 \pm 2.5 \mu \mathrm{g} / \mathrm{ml}$.

We next compared the effect of the hydroalcoholic extract on high density (resting) B cells with its effect on low density (in vivo preactivated) B cells and observed (Figure $2 \mathrm{~A}$ ) that the latter were more resistant to the inhibitory effect of the extract. These data suggest that the inhibitory effect of the hydroalcoholic extract may probably be an early effect that would not be observed once the cells were activated. To test this hypo-
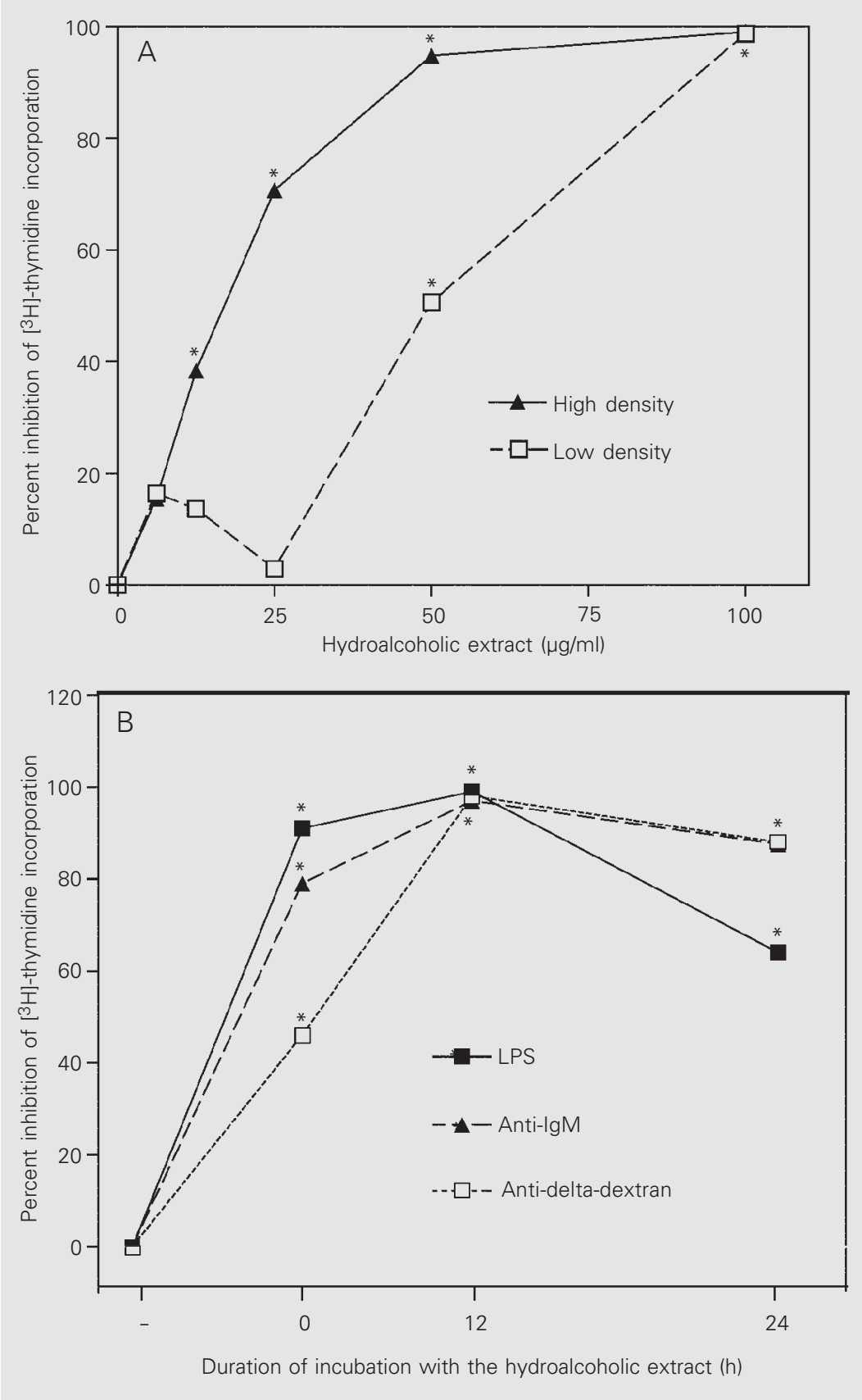

Figure 2. Comparison of the inhibitory effect of the hydroalcoholic extract of Cissampelos sympodialis Eichl in cultures of either resting or preactivated B cells.

A, Analysis of the effect of the hydroalcoholic extract on the response of resting (high density) and in vivo preactivated (low density) cells. Murine spleen B cells were obtained and fractionated on a Percoll gradient. High density and low density $B$ cells were obtained and were cultivated $\left(2 \times 10^{5}\right.$ cells/well in $\left.0.2 \mathrm{ml}\right)$ for 48 $\mathrm{h}$ in the presence of lipopolysaccharide (LPS, $10 \mu \mathrm{g} / \mathrm{ml}$ ) and treated or not with the indicated doses of the hydroalcoholic extract. Proliferation was measured by the incorporation of $1 \mu \mathrm{Ci}$ tritiated thymidine after an 18-h pulse. Cultures were carried out in triplicate. Nonstimulated cultures showed an average incorporation of $1,410 \mathrm{cpm}$. The data are reported as percent inhibition of the proliferative response observed in the presence of the hydroalcoholic extract compared to values for control untreated cultures, which were $35,120 \mathrm{cpm}$ for high density $B$ cells and $34,865 \mathrm{cpm}$ for low density $B$ cells. The statistical significance $\left({ }^{*} P<0.05\right)$ was obtained by comparing data for cultures stimulated with the hydroalcoholic extract to those for unstimulated cultures by the Student $t$-test.

$B$, Kinetics of the inhibition of the proliferative response of $\mathrm{B}$ cells by the hydroalcoholic extract. High density spleen B cells were cultivated $\left(2 \times 10^{5}\right.$ cells/well in 0.2 $\mathrm{ml}$ ) for $48 \mathrm{~h}$ in the presence or absence of the indicated stimuli (LPS, $10 \mu \mathrm{g} / \mathrm{ml}$; anti-delta-dextran, $10 \mathrm{ng} / \mathrm{ml}$, or goat anti-mouse lgM, $10 \mu \mathrm{g} / \mathrm{ml})$. The cultures were treated with the hydroalcoholic extract (added at 50 $\mu \mathrm{g} / \mathrm{ml})$ at the indicated times after the beginning of the cultures. Proliferation was measured by the incorporation of $1 \mu \mathrm{Ci}$ tritiated thymidine after an 18-h pulse. The data are reported as percent inhibition of proliferation in cultures to which the hydroalcoholic extract was added. The control values (culture stimulated in the absence of the hydroalcoholic extract) were as follows: LPS, 14,146 cpm; anti-lgM, 4,897 cpm; antidelta-dextran, 26,358 cpm. Thymidine incorporation was $488 \mathrm{cpm}$ for nonstimulated cultures. Three independent experiments (data not shown) gave similar results. ${ }^{*} P<0.05$ for cultures stimulated with the hydroalcoholic extract compared to unstimulated cultures (Student $t$-test). 
thesis, we performed kinetic studies in which the hydroalcoholic extract was added to cultures at different times. We observed that the hydroalcoholic extract inhibited cell proliferation even when added to the culture at later times (12 and $24 \mathrm{~h}$ after the beginning of culture; Figure 2B).

To assess the effect of the hydroalcoholic extract on another B cell activation system, we tested its effect on the response induced by stimulation of $\mathrm{B}$ cells preactivated in vitro with anti-MHC class II antibodies. High density B cells were stimulated with antiIgM antibody plus IL-4 and were then restimulated with either anti-MHC class II antibody or LPS and the hydroalcoholic extract was added to these secondary cultures. We observed that under these experimental conditions preactivated cells stimulated with antiMHC class II antibody became completely refractory to the inhibitory effect of the hydroalcoholic extract and their proliferative response was increased by the addition of the hydroalcoholic extract (Figure 3A). However, secondary cultures stimulated with LPS were still sensitive to inhibition with the hydroalcoholic extract (Figure 3B).

\section{Effect of the hydroalcoholic extract on cAMP levels in B cell cultures}

To determine the possible mechanism of the effect of the hydroalcoholic extract on $B$ cells we measured the cAMP levels of B cells stimulated in the presence of the hydroalcoholic extract. As shown in Figure $4 \mathrm{~A}$, the treatment of resting $\mathrm{B}$ cells with the hydroalcoholic extract induced a significant increase in cytoplasmic cAMP levels when compared to control cultures. Forskolin was used as a standard control drug, since it increases intracytoplasmic cAMP levels. We also obtained $\mathrm{B}$ cell blasts activated in the presence of IL-4 and anti-IgM and incubated them in a secondary culture with either LPS or anti-MHC class II antibody. We observed (Figure 4B) that the hydroalcoholic extract increased cAMP levels in cultures stimulated with LPS, but decreased them when these blasts were stimulated with anti-MHC class II antibody. Cells preactivated with IL-4 and IgM showed elevated basal cAMP levels when compared to nonstimulated cells.

\section{In vitro IgM production is inhibited by the hydroalcoholic extract}

After determining the effect of the $C$. sympodialis-derived hydroalcoholic extract on the B cell proliferative response, we next determined its effect on IgM production. As shown in Figure 5A, the hydroalcoholic extract inhibited IgM secretion in spite of the $\mathrm{B}$ cell activator used. This inhibitory effect was observed even when the hydroalcoholic extract was added $72 \mathrm{~h}$ after the beginning of culture (data not shown). The production of
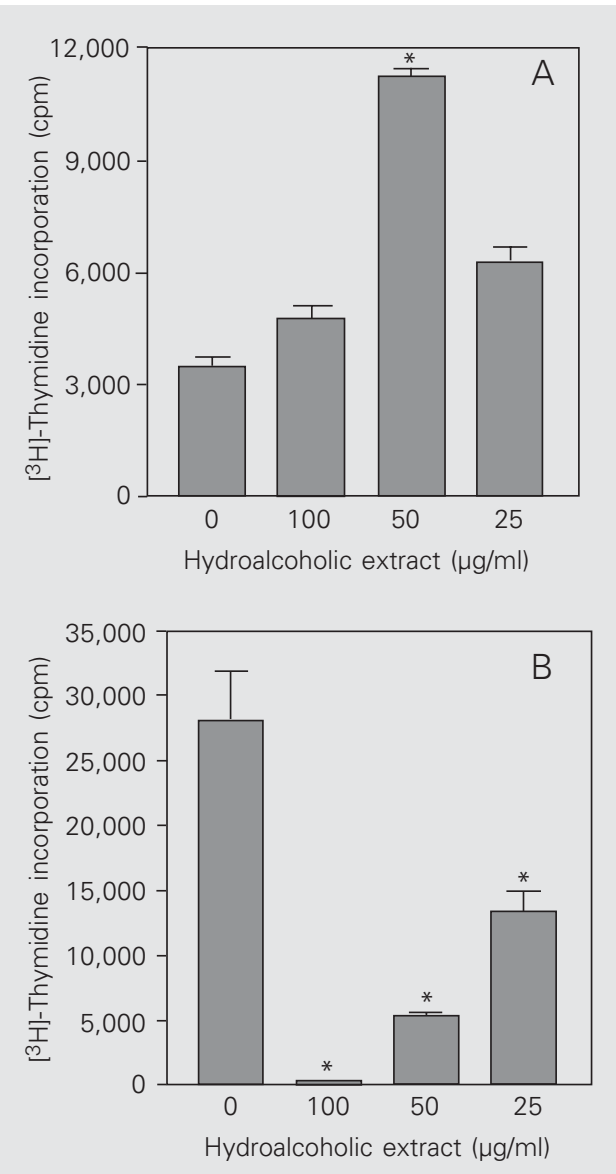

Figure 3. The hydroalcoholic extract of Cissampelos sympodialis Eichl inhibited the proliferation of in vitro-activated B cells induced by LPS but not the response induced by anti-MHC class II antibody. Resting (high density) spleen B cells were obtained and cultivated (106 cells/ well in $1 \mathrm{ml}$ ) in the presence of goat anti-mouse $\operatorname{lgM}$ antibody $(100 \mu \mathrm{g} / \mathrm{ml})$ and IL-4 $(300 \mathrm{U} / \mathrm{ml})$. After $24 \mathrm{~h}$ of culture, the blasts were harvested and reincubated in a secondary culture $\left(2 \times 10^{5}\right.$ cells/well in $0.2 \mathrm{ml}$ ) for $48 \mathrm{~h}$. Some secondary cultures (A) were set up on plates previously coated with monoclonal anti$\mathrm{MHC}$ class II antibody (anti-class II, used at $10 \mu \mathrm{g} / \mathrm{ml}$ ). Other secondary cultures (B) were stimulated with lipopolysaccharide (LPS, $10 \mu \mathrm{g} / \mathrm{ml}$ ) on uncoated plates. The secondary cultures were also treated with the indicated doses of the hydroalcoholic extract. Proliferation was measured by the incorporation of $1 \mu \mathrm{Ci}$ tritiated thymidine after an 18-h pulse. The data indicate the values of tritiated thymidine incorporation of hydroalcoholic extract-treated and -untreated cultures. ${ }^{*} \mathrm{P}<0.05$ for hydroal coholic extract-treated cultures compared to untreated cultures (Student $t$-test). 
IgM was more sensitive to the effect of the extract than the proliferative response. We did not observe any significant difference in the inhibition of IgM secretion mediated by the hydroalcoholic extract when comparing the in vitro response of high density or low density B cells (data not shown). To further compare the effect of the hydroalcoholic extract on the response of resting and preactivated $\mathrm{B}$ cells, we investigated the effect of the hydroalcoholic extract on immunoglobulin secretion by B cells obtained from

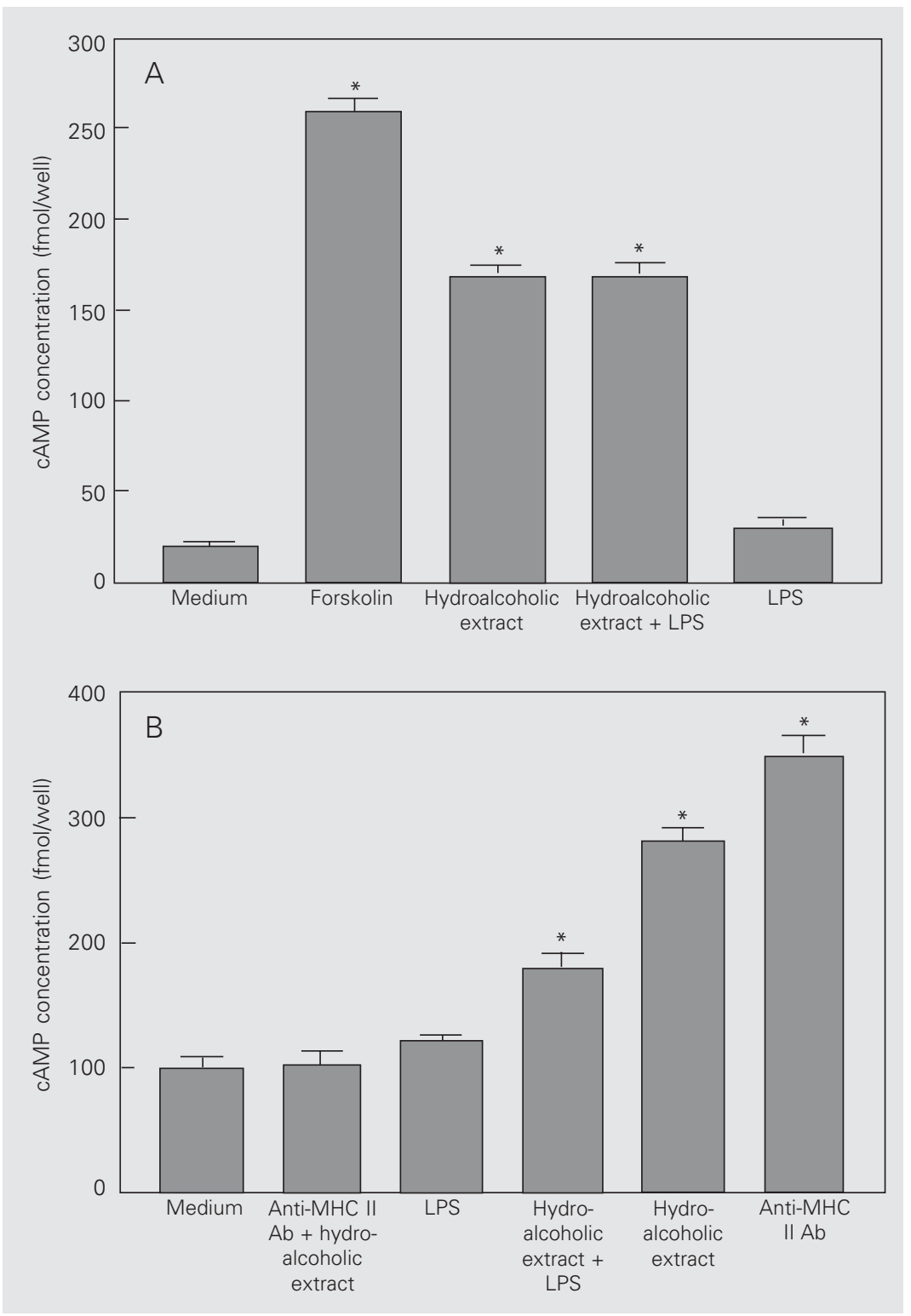

T. cruzi-infected mice. We observed (Figure 5B) that the hydroalcoholic extract inhibited IgM secretion by the cells from T. cruziinfected animals to a greater extent than by cells obtained from normal mice. While the concentration of $6.5 \mu \mathrm{g} / \mathrm{ml}$ inhibited the LPSinduced response of cells from normal animals by $20 \%$, the same concentration inhibited the response of B cells obtained from $T$. cruzi-infected animals by $75 \%$. We also observed that the proliferative response of $\mathrm{B}$ cells from $T$. cruzi-infected mice was more affected by the hydroalcoholic extract than the response of $\mathrm{B}$ cells from normal mice (data not shown). The mean $\mathrm{IC}_{50}$ of the hydroalcoholic extract was 3.5 times lower in the LPS-induced proliferative response of cells from $T$. cruzi-infected mice than in the LPS-induced response of B cells from normal mice (data not shown).

Figure 4. cAMP levels in spleen B cell cultures incubated in the presence of the hydroalcoholic extract of Cissampelos sympodialis Eichl.

A, High density (resting) B cells. High density spleen B cells were cultivated $\left(2 \times 10^{5}\right.$ cells/well in $\left.0.2 \mathrm{ml}\right)$ for $2 \mathrm{~h}$ in the presence of the indicated reagents: $10 \mu \mathrm{g} / \mathrm{ml}$ lipopolysaccharide (LPS), $50 \mu \mathrm{g} / \mathrm{ml}$ hydroalcoholic extract, and $10 \mu \mathrm{M}$ forskolin. cAMP levels were measured by an immunoenzymatic assay. The data are representative of three independent experiments.

$B$, In vitro preactivated blasts. Resting (high density) spleen B cells were obtained and cultivated $\left(10^{6}\right.$ cells/ well in $1 \mathrm{ml}$ ) in the presence of goat anti-mouse lgM antibody $(100 \mu \mathrm{g} / \mathrm{ml})$ and $\mathrm{IL}-4(300 \mathrm{U} / \mathrm{ml})$. After $24 \mathrm{~h}$ of culture, the blasts were harvested and reincubated in a secondary culture $\left(2 \times 10^{5}\right.$ cells/well in $\left.0.2 \mathrm{ml}\right)$ for $2 \mathrm{~h}$. Some secondary cultures were set up on plates previously coated with monoclonal anti-MHC class II antibody (used at $10 \mu \mathrm{g} / \mathrm{ml}$ ) and others were set up on uncoated plates and were either left unstimulated or were stimulated with LPS $(10 \mu \mathrm{g} / \mathrm{ml})$. The hydroalcoholic extract $(50 \mu \mathrm{g} / \mathrm{ml})$ was added to the indicated cultures. CAMP levels were measured by an immunoenzymatic assay. The data are representative of three independent experiments. Anti-MHC $\| \mathrm{Ab}$ indicates cultures stimulated on plates coated with anti-MHC class II antibody. ${ }^{*} \mathrm{P}<0.05$ for cAMP levels obtained in cultures with different additions compared to control untreated cultures (Student $t$-test). 


\section{Discussion}

We investigated the immunomodulatory effect of the aqueous fraction of the ethanol extract of $C$. sympodialis. Previous studies have shown that this extract suppressed the $\mathrm{T}$ cell response and also modified the pattern of cytokine secretion to a Th2 profile (10). The effect on B cells was shown indirectly by the demonstration that in vivo treatment with the hydroalcoholic extract decreased the production of IgE by guinea pigs immunized with ovalbumin (Piuvezam MR, unpublished data).

In the present study we investigated the response of B lymphocytes stimulated in vitro by binding of anti-IgM and conjugated anti-IgD antibodies to the $\mathrm{B}$ cell receptor. B cells were also stimulated with LPS, antiMHC class II antibodies, and cytokines (IL4). Different activators were used since distinct activators induce several different $B$ cell response profiles $(12,15)$. The response

Figure 5. Inhibition of IgM production in cultures stimulated in the presence of the hydroalcoholic extract of Cissampelos sympodialis Eichl.

A, High density spleen $B$ cells were cultivated $(2.5 \times$ $10^{4}$ cells/well in $0.2 \mathrm{ml}$ ) for 7 days in the presence or absence of the following stimulators: lipopolysaccharide (LPS, 10 Hg/ml), IL-4 (300 U/ml), IL-4 + IL-5 (300 U/ $\mathrm{ml}$ of each) or a combination of IL-4 + IL-5 and antidelta-dextran (used at $10 \mathrm{ng} / \mathrm{ml}$ ). Some cultures were treated with the indicated doses of the hydroalcoholic extract. IgM levels were measured in pooled culture supernatants by capture ELISA. The data shown indicate the percent inhibition of IgM production in extracttreated cultures compared with control untreated cultures. Control levels of $\mathrm{lgM}$ were as follows: LPS, 6,500 ng/ml; IL-4, $147 \mathrm{ng} / \mathrm{ml}$; IL-4 + IL-5, $390 \mathrm{ng} / \mathrm{ml}$, and IL-4 + IL-5 + anti-delta-dextran, $540 \mathrm{ng} / \mathrm{ml}$. ${ }^{*} \mathrm{P}<$ 0.05 for cultures treated with the hydroalcoholic extract compared to untreated cultures (Student $t$-test). The data are representative of three independent experiments.

$B$, High density spleen cells were obtained from either normal or Trypanosoma cruzi-infected mice and cultivated $\left(2.5 \times 10^{4}\right.$ cells/well in $\left.0.2 \mathrm{ml}\right)$ for 7 days in the presence of LPS $(10 \mu \mathrm{g} / \mathrm{ml})$. Some cultures were also treated with the indicated doses of the hydroalcoholic extract. IgM levels were measured by capture ELISA. induced by anti-delta-dextran and soluble anti-IgM antibodies has been well characterized. It was shown that these activators stimulate $\mathrm{B}$ cell proliferation and that this response is increased by cytokines $(12,22,23)$. The proliferative response was inhibited in spite of the activator used, showing that the inhibitory effect of the hydroalcoholic extract was not specific for the response stimulated by LPS.

The inhibitory effect of the hydroalcoholic extract could not merely be reversed by

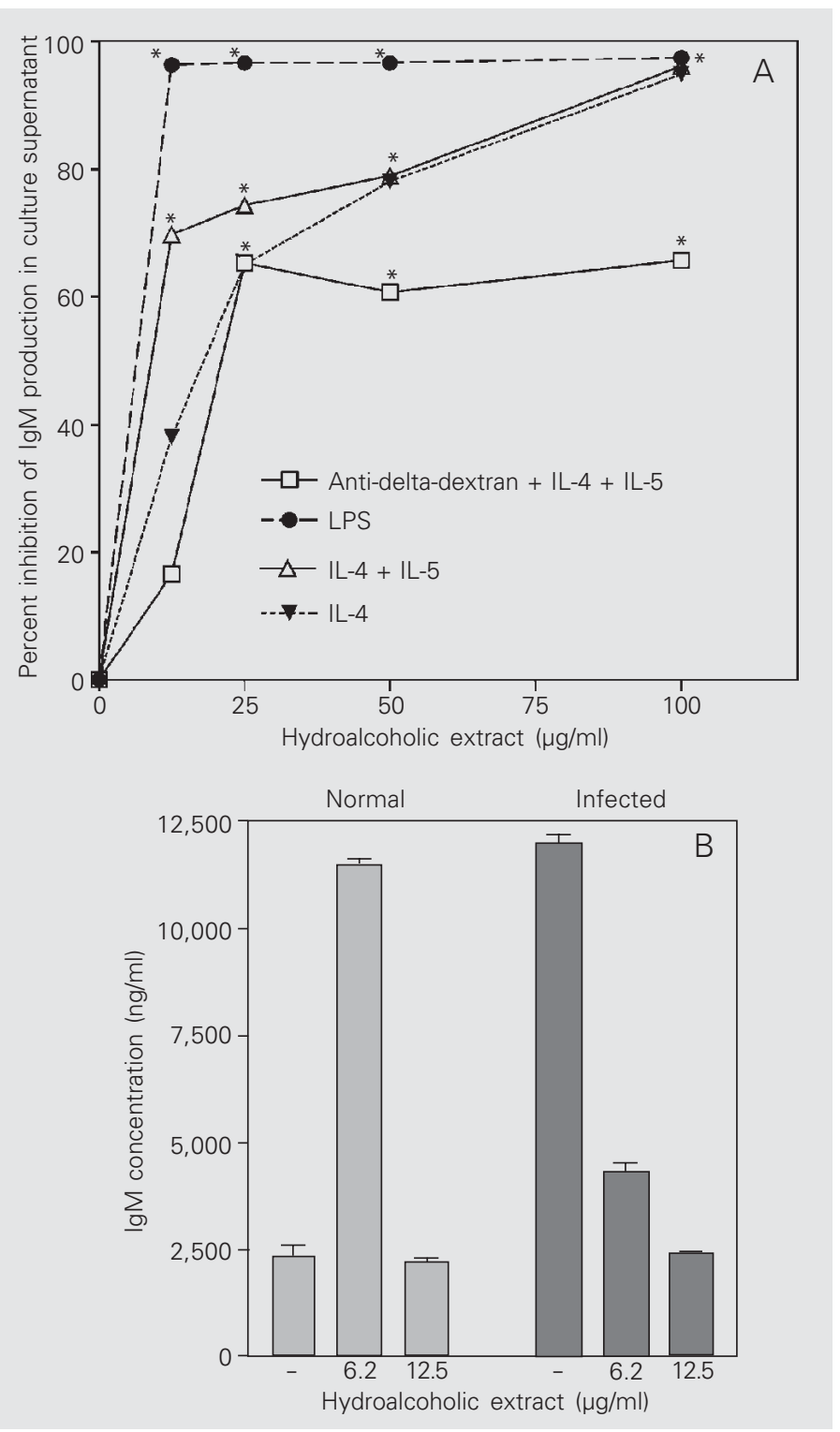


previous B cell activation, since both resting (high density) and preactivated (low density) B cells were sensitive to the hydroalcoholic extract. High density B cells have been described as cells that have not entered the antigen-driven proliferation phase. Low density cells are cells that have already had some contact with antigens in vivo (24). The difference in the pattern of response of different B cell subpopulations could be attributed to distinct degrees of signaling transduction through the B cell receptor (25). This difference may probably be associated with a lower $\mathrm{Ca}^{2+}$ release by high density cells, when compared with low density cells (26). Based on these findings, it is possible to suggest that, because low density cells may have higher levels of intracellular second messengers, we needed higher doses of the hydroalcoholic extract to block their activation.

Our findings suggest that the hydroalcoholic extract may stimulate the induction of a potent inhibitory signal. We tested the hypothesis that the inhibitory effect of the hydroalcoholic extract on B lymphocytes may be due to an increase in cAMP levels. The hydroalcoholic extract was able to increase cAMP levels in resting and preactivated $B$ cells even when added alone. Previous studies have shown that the hydroalcoholic extract inhibits some enzymatic systems such as the phosphodiesterase one (8), that is linked to the inactivation of cAMP. It is possible that these enzymes are being inactivated in B lymphocytes incubated with the hydroalcoholic extract as well.

Several studies have identified cAMP as an antagonist of B cell proliferation induced by mitogens (27). It was observed that the pharmacological increase of intracellular cAMP levels also inhibited the B lymphocyte response $(28,29)$. Recently, it was demonstrated that cAMP is a second messenger that plays an important role in the regulation of B cell apoptosis (30). Also, in general, an increase in cAMP levels is associated with anti-inflammatory and immunosuppressive effects $(31,32)$. Despite this inhibitory effect, there is evidence that an increase in intracellular cAMP may also be a signal associated with lymphocyte differentiation. It was recently shown that stimulation of $\mathrm{B}$ cells with high doses of anti-IgD antibodies induces an increase in cytoplasmic cAMP that is associated with the differentiation into a germinal center type cell population (33). Increase in cAMP levels can also increase class switching to IgG1 (34).

Despite evidence showing an increase in intracellular cAMP levels in resting cells stimulated with anti-MHC class II antibodies and a consequent inhibition of the $\mathrm{B}$ cell response, this signal has no inhibitory effect on the response of in vitro preactivated $\mathrm{B}$ cells (35). It was shown (35) that B cells preactivated with IL-4 and anti-IgM antibody become competent and capable of mobilizing intracellular $\mathrm{Ca}^{2+}$ through the binding of antibodies to surface class II MHC. Based on these features of the response of cells preactivated with anti-IgM and IL-4, we hypothesized that, if the major effect of the hydroalcoholic extract is the induction of increased intracellular cAMP levels, this extract would have no major effect on the response of cells preactivated with anti-IgM and IL-4 and incubated with anti-MHC class II antibody. The data obtained here confirmed this hypothesis. This finding may possibly indicate that cAMP levels are regulated in a different manner in B cells activated through the binding of antibody to the MHC molecule but further studies would be necessary to clarify this point.

Having characterized the mechanism of inhibition of the $\mathrm{B}$ cell proliferative response by the hydroalcoholic extract, we analyzed the effect of this extract on IgM secretion. We observed that the hydroalcoholic extract also had an inhibitory effect on this B cell response. We further tested whether the hydroalcoholic extract would have any effect on cells that are already secreting high levels of immunoglobulin. To perform this study, 
we used B cells isolated from T. cruzi-infected mice. During the acute phase of $T$. cruzi infection there is polyclonal B lymphocyte activation (36). With the progression of the disease, the number of immunoglobulinsecreting cells is increased and hypergammaglobulinemia is detected (37). We observed that the response of these cells was also sensitive to the effect of the hydroalcoholic extract. The polyclonal B cell activation detected during $T$. cruzi infection seems to have pathological consequences for the host, since mice with a genetically determined defect in B cell response showed neither polyclonal B cell activation nor heart tissue pathology (38). Our findings that the hydroalcoholic extract could decrease immunoglobulin secretion by preactivated $\mathrm{B}$ cells obtained from $T$. cruzi-infected mice open the possibility for a therapeutic use of the extract from $C$. sympodialis in conditions associated with dysregulated B cell function or increased immunoglobulin secretion.

One important finding obtained in the current study was the observation that even activated cells could be inhibited by the hydroalcoholic extract, depending on the nature of the $B$ cell activator used. This inhibitory effect on B cells could be one more mechanism of the anti-inflammatory effect of this extract.

\section{Acknowledgments}

The authors are indebted to Mr. Sidney Gomes da Costa and Mr. Nelson Martins Ferreira (Departamento de Imunologia, IMPPG, UFRJ, Rio de Janeiro, RJ, Brazil) for expert technical assistance. We thank Dr. James J. Mond (Biosynexus Inc., Gaithersburg, MD, USA) for providing the anti-deltadextran conjugate and Dr. Patricia M. Rodrigues e Silva (Fundação Oswaldo Cruz, Rio de Janeiro, RJ, Brazil) for providing rolipran and forskolin. We also thank Dr. Lucia Mendonça Previato (Instituto de Biofísica Carlos Chagas Filho, UFRJ, Rio de Janeiro, RJ, Brazil) for performing the LPS measurements.

\section{References}

1. Barbosa-Filho JM, Agra MF \& Thomas G (1997). Botanical, chemical and pharmacological investigation on $C$. sympodialis from Paraíba (Brazil). Journal of the Brazilian Association for the Advancement of Science (Ciência e Cultura), 49: 386-394.

2. Dwama-Badu D, Ayim JSK, Mingle CA, Tackie AN, Slatkin DJ, Knapp JE \& Schiff PL (1975). Alkaloids of C. pareira. Phytochemistry, 14: 2520-2521.

3. Bhakuni DS, Jain S \& Chaturvedi R (1987). The biosynthesis of alkaloids of $C$. pareira Linn. Tetrahedron, 42: 3975-3976.

4. Freitas MR, Cortes SF, Thomas G \& Barbosa-Filho JM (1996). Modification of $\mathrm{Ca}^{2+}$ metabolism in the rabbit aorta as a mechanism of spasmolytic action of wariftein, a bisbenzylisoquinoline alkaloid isolated from the leaves of $C$. sympodialis Eichl. (Menispermaceae). Journal of Pharmacy and Pharmacology, 48: 333-336.

5. Thomas G, Araujo CC, Duarte JC \& Souza DP (1997). Bronchodilatatory activity of an aqueous fraction of the ethanolic extract of the leaves of $C$. sympodialis Eichl. (Menispermaceae) in the guinea pig. Phytomedicine, 4: 233-238.

6. Batista-Lima KV, Ribeiro RA, Balestieri FMP, Thomas G \& Piuvezam MR (2001). Anti-inflammatory activity of Cissampelos sympodialis Eichl (Menispermaceae) leaf extract. Acta Farmacologica Bonaerense, 20: 275-279.

7. Thomas G, Burnes F, Pyne S \& Pine NJ (1997). Characterization of an extract from the leaves of $C$. sympodialis Eichl on spontaneous tone of isolated trachea. Phytotherapy Research, 11: 496-499.

8. Thomas G, Selak M \& Henson P (1999). Effects of the aqueous fraction of the ethanolic extract of the leaves of $C$. sympodialis Eichl in human neutrophils. Phytotherapy Research, 13: 9-13.

9. Cortes SF, Alencar JL, Thomas G \& Barbosa-Filho JM (1995). Spasmolytic actions of wariftein, a bisbenzylisoquinoline alkaloid from the root bark of C. sympodialis Eichl. Phytotherapy Research, 9: 579-583.

10. Piuvezam MR, Peçanha LMP, Alexander J \& Thomas G (1999). Cissampelos sympodialis Eichl leaf extract increases the production of IL-10 by concanavalin-A-treated BALB/c spleen cells. Journal of Ethnopharmacology, 67: 93-101.

11. Alexandre-Moreira MS, Freire-de-Lima CG, Trindade MN, CastroFaria-Neto HC, Piuvezam MR \& Peçanha LMT (2003). Cissampelos sympodialis Eichl (Menispermaceae) leaf extract induces interleukin-10-dependent inhibition of Trypanosoma cruzi killing by macrophages. Brazilian Journal of Medical and Biological Research, 36: 199-205.

12. Mond JJ, Lees A \& Snapper CM (1995). T cell independent antigens type 2. Annual Review of Immunology, 13: 655-692.

13. Lane PJL, McConnell GM, Schieven GL, Clark EA \& Ledbetter JA (1990). The role of class II molecules in human B cell activation: 
association with phosphatidylinositol turnover, protein tyrosine phosphorylation and proliferation. Journal of Immunology, 144: 3684-3692.

14. Cambier JC, Newell MK, Justement LB, Leach KL, McGuire JC \& Chen ZZ (1987). la binding ligands and CAMP induced nuclear translocation of protein kinase C. Nature, 327: 629-632.

15. Snapper CM \& Mond JJ (1993). Towards a comprehensive view of immunoglobulin class switching. Immunology Today, 14: 15-17.

16. Barnes PJ (1996). Pathophysiology of asthma. British Journal of Clinical Pharmacology, 42: 3-10.

17. Carreira J, Jones C, Wait R, Previato JO \& Mendonça-Previato L (1996). Structural variation in the glycoinositolphospholipids of different strains of Trypanosoma cruzi. Glycoconjugate Journal, 13: 955-966.

18. Contreras VT, Salles JM, Thomas N, Morel CM \& Goldenberg S (1985). In vitro differentiation of Trypanosoma cruzi under chemically defined conditions. Molecular and Biochemical Parasitology, 16: 315-327

19. Lopes M, Cunha JMT, Bezerra FL, Gonçales MS, Gomes JEL, Silva JRL, Garcia ES \& dos Reis GA (1995). Trypanosoma cruzi: both chemically induced and triatomine-derived metacyclic trypomastigotes cause the same immunological disturbance in the infected mammalian host. Experimental Parasitology, 80: 194-204.

20. Brunswick M, Finkelman FD, Highet $P$, Inman JK, Dintiz H \& Mond JJ (1988). Picogram quantities of anti-Ig antibodies coupled to dextran induce B cell proliferation. Journal of Immunology, 140: 33643369.

21. Snapper CM \& Paul WE (1987). B cell stimulatory factor 1 (interleukin 4) prepares resting murine B cells to secrete lgG1 upon subsequent stimulation with bacterial lipopolysaccharide. Journal of Immunology, 139: 10-17.

22. Phillips C \& Klaus GGB (1992). Soluble anti- $\mu$ monoclonal antibodies prime $B$ cells to secrete immunoglobulin in response to interleukin4 and -5. European Journal of Immunology, 22: 1541-1545.

23. Peçanha LMT, Snapper CM, Finkelman FD \& Mond JJ (1991). Dextran-conjugated anti-lg antibodies as a model for $T$ cell-independent type 2 antigen-mediated stimulation of Ig secretion in vitro. Journal of Immunology, 146: 833-839.

24. MacLennan JCM \& Gray D (1986). Antigen-driven selection of virgin and memory B cells. Immunologic Research, 91: 61-85.

25. Gilbert JJ (1998). Antagonist role for phospholipase D activities in B cell signaling: while the antigen receptors transduce mitogenic signals via a novel phospholipase D activity, phosphatidylcholinephospholipase D mediates antiproliferative signal. Journal of Immunology, 161: 6575-6584.

26. Marshal AJ, Niiro H, Yun TJ \& Clark EA (2000). Regulation of B cell activation and differentiation by the phosphatidylinositol 3-kinase and phospholipase C gamma pathways. Immunological Reviews, 176: 30-46.

27. Cohen DP \& Rothstein TL (1989). Adenosine $3^{\prime}, 5^{\prime}$-cyclic monophosphate modulates the mitogenic response of murine B lymphocytes. Cellular Immunology, 121: 113-119.

28. Naderi S \& Blomhoff HK (1999). Mad1 expression in the absence of differentiation: effect of cAMP on the B lymphoid cell line Reh. Journal of Cellular Physiology, 178: 76-84.

29. Naderi S, Gutzkow BK, Christoffersen J, Smeland EB \& Blomhoff HK (2000). cAMP-mediated growth inhibition of lymphoid cells in G1: rapid down-regulation of cyclin D3 at the level of translation. European Journal of Immunology, 30: 1757-1768.

30. Myklebust JH, Josefsen D, Blomhoff HK, Levy K, Finn O, Naderi S, Reed JC \& Smeland EB (1999). Activation of cAMP signaling pathway increases apoptosis in human B precursor cells and is associated with down regulation of $\mathrm{Mcl}-1$ expression. Journal of Cellular Physiology, 180: 71-80.

31. Wong WSF \& Koh DSK (2000). Advances in immunopharmacology of asthma. Biochemical Pharmacology, 59: 1323-1355.

32. Torgersen KM, Vang T, Abrahamsen H, Yaqub S \& Tasken K (2002). Molecular mechanisms for protein kinase-A mediated modulation of immune function. Cellular Signalling, 14: 1-9.

33. Chaturvedi A, Siddqui Z, Bayiroglu F \& Rao KVS (2002). A GPI-linked isoform of the $\operatorname{lgD}$ receptor regulates resting $B$ cell activation. Nature Immunology, 3: 951-957.

34. Roper RL, Graf B \& Phipps RP (2002). Prostaglandin E2 and cAMP promote B lymphocyte class switching to lgG1. Immunology Letters, 84: 191-198.

35. Cambier JC, Morrison DC, Chen MM \& Lehmann KR (1991). Modeling of $T$ cell contact dependent B cell activation: IL-4 and antigen receptor ligation primes quiescent $B$ cells to mobilize calcium in response to la cross-linking. Journal of Immunology, 146: 20752082.

36. Ortiz-Ortiz L, Parks DE, Rodriguez M \& Weigle WO (1980). Polyclonal B lymphocyte activation during Trypanosoma cruzi infection. Journal of Immunology, 124: 121-126.

37. D'Imperio Lima MR, Eisen $H$, Minoprio $P$, Joskowicz M \& Coutinho A (1986). Persistence of polyclonal B cell activation with undetectable parasitemia in late stages of experimental Chagas' disease. Journal of Immunology, 137: 353-356.

38. Minoprio P, El Cheikh MC, Murphy E, Honteybere-Joskowicz M, Coffman R, Coutinho A \& O'Garra A (1993). Xid-associated resistance to experimental Chagas' disease is IFN-gamma dependent. Journal of Immunology, 151: 4200-4208. 